RESEARCH ARTICLE

Ali Sapmaz ${ }^{1}$

D Cem Emir Guldogan²

D Betul Keskinkilc Yagiz ${ }^{1}$

Ahmet Serdar Karaca ${ }^{3}$

${ }^{1}$ Ankara Bilkent City

Hospital General Surgery

Department, Ankara, Turkey

${ }^{2}$ Ankara Liv Hospital

General Surgery

Department, Ankara, Turkey

${ }^{3}$ İstanbul Baskent University

Hospital General Surgery

Department, Istanbul,

Turkey
Corresponding Author:

Ali Sapmaz

1Ankara Bilkent City Hospital General Surgery Department,

Ankara, Turkey mail:

alisapmaz@gmail.com

Received: 02.06.2020

Acceptance: 25.09 .2020

DOI:10.18521/ktd.747234
Konuralp Medical Journal e-ISSN1309-3878

konuralptipdergi@duzce.edu.tr konuralptipdergisi@gmail.com www.konuralptipdergi.duzce.edu.tr

\section{Incidental Gallbladder Cancer Diagnosed During Or After Laparoscopic Cholecystectomy, What Did We Do ? \\ ABSTRACT}

Objective: Gallbladder cancer is a rare neoplasm. We report our experience with gallbladder cancer that was incidentally diagnosed during or after laparoscopic cholecystectomy performed for gallstone disease.

Methods: This study included all laparoscopic cholecystectomies due to gallstone disease undertaken from January 2010 to April 2015. Exclusion criteria were suspicion of malignancy and/or existence of gallbladder polyps detected with ultrasonography preoperatively. Patients with incidentally diagnosed gallbladder cancer were recorded, and the clinical and demographic characteristics of these patients were reviewed.

Results: Of 6,114 patients in whom laparoscopic cholecystectomy was attempted, 5.948 were included in this study. Incidental gallbladder cancer was found in thirty-six patients, with a mean age of 64.08 years. The histological tumor stages were adenocarcinoma in situ in seven patient, pT1b in nine patient, pT2 in eleven patient, and pT3 in nine patients. Sixteen patients who underwent laparoscopic cholecystectomy alone underwent no additional surgery because of the low stage of the tumors. The twenty remaining patients, whose laparoscopic cholecystectomies were converted to open surgeries, underwent cholecystectomy, excision of the liver bed and lymph node dissection. The overall median survival time was 28 months.

Conclusions: The incidence of incidental gallbladder cancer has been reported to vary, up to $2.85 \%$. In this single-center study, the rate of incidental gallbladder cancer was found to be $0.60 \%$. Female gender and advanced age are demographic risk factors for gallbladder carcinoma. Although gallbladder cancer is well known for its poor prognosis, tumors that are incidentally diagnosed are often found at an early stage and have a better prognosis.

Keywords: Cholecystectomy, Gallbladder Carcinoma, Incidence, Laparoscopy, Prognosis

\section{Laparoskopik Kolesistektomi Sırasında veya Sonrasında Teşhis Edilen İncidental Safra Kesesi Kanseri. Biz Ne Yaptık? \\ ÖZET}

Amaç: Safra kesesi kanseri nadir görülen bir neoplazmdır. Kolelitiazis nedeni ile yapılan laparoskopik kolesistektomi sırasında veya sonrasında tesadüfen teşhis edilen safra kesesi kanseri ile ilgili deneyimlerimizi sunuyoruz.

Gereç ve Yöntem: Bu çalışma, Ocak 2010'dan Nisan 2015'e kadar yapılan kolelitiazis e bağlı tüm laparoskopik kolesistektomileri içermiş̧ir. Çalışmada dışlama kriterleri; ameliyat öncesi ultrasonografi ile tespit edilen malignite şüphesi ve / veya safra kesesi poliplerinin varlığıydı. Safra kesesi kanseri tanısı konan hastalar incelendi ve bu hastaların klinik ve demografik özellikleri gözden geçirildi.

Bulgular: Laparoskopik kolesistektomi yapılan 6,114 hastadan 5,948'i çalışmaya dahil edildi. Yaş ortalaması 64,08 olan otuzaltı hastada rastlantısal safra kesesi kanseri saptandı. Histolojik tümör evreleri yedi hastada in situ adenokarsinom, dokuz hastada pT1b, onbir hastada pT2 ve dokuz hastada pT3 idi. Sadece laparoskopik kolesistektomi yapılan 16 hastaya tümörlerin düşük evresi nedeniyle ek cerrahi uygulanmadı. Laparoskopik kolesistektomileri açık ameliyatlara dönüştürülen kalan 20 hastaya kolesistektomi, karaciğer yatağı eksizyonu ve lenf nodu diseksiyonu uygulandı. Genel ortalama sağkalım süresi 28 aydı.

Sonuç: İnsidental safra kesesi kanseri insidansının \% 2,85'e kadar olabildiği bildirilmiştir. $\mathrm{Bu}$ tek merkezli çalışmada, rastlantısal safra kesesi kanseri oranı \% 0,60 olarak bulunmuştur. Kadın cinsiyet ve ileri yaş safra kesesi karsinomu için demografik risk faktörleridir. Safra kesesi kanseri kötü prognozu ile iyi bilinmesine rağmen, tesadüfen teşhis edilen tümörler sıklıkla erken bir aşamada bulunur ve daha iyi bir prognoza sahiptir.

Anahtar Kelimeler: Kolesistektomi, Safra Kesesi Karsinomu, İnsidans, Laparoskopi, Prognoz 


\section{INTRODUCTION}

Gallbladder cancer is the fifth most common gastrointestinal cancer (1). It is well known for its poor prognosis, and $15-30 \%$ of patients show no preoperative or intraoperative evidence of gallbladder cancer (2). Gallstone disease, porcelain gallbladder, sclerosing cholangitis, and advanced age are the best known risk factors for gallbladder cancer. Laparoscopic cholecystectomy (LC) has been the gold standard treatment for gallstone disease for over two decades. LC performed for gallstone disease rarely results in a diagnosis of unexpected gallbladder cancer. In the Englishlanguage research literature, the incidence of gallbladder cancer diagnosed during or after LC is $0.2 \%-2.85 \%$ (3-11). In this single-center study, we report our experience with gallbladder cancer incidentally diagnosed during or after LC performed for gallstone disease.

\section{MATERIAL AND METHODS}

We evaluated the medical records of patients with gallstone disease who underwent LC in the Surgery Department of Ankara Numune Research and Education Hospital over the past 5 years. Routine preoperative assessment was performed in all patients, including liver biochemical assessment and abdominal ultrasonography of the hepatobiliary system. Exclusion criteria were suspicion of malignancy and/or existence of gallbladder polyps detected during preoperative ultrasonography. All operations were carried out by senior surgeons or trainees under supervision using the standard fourport, two-hand technique. Following direct $10 \mathrm{~mm}$ trocar insertion, a $15 \quad \mathrm{mmHg} \quad \mathrm{CO} 2$ pneumoperitoneum was created. Intraoperative cholangiograms and drains were used when necessary. The presence of a nodular pattern and/or irregularity in the gallbladder wall during or after dissection was evaluated as a cause for suspicion of cancer. Tumor staging was based on the 7th edition of the American Joint Committee on Cancer (AJCC) manual (12). Recorded data included patient demographics, operative procedures, perioperative outcomes, tumor histopathology, follow-up, and long-term survival. Postoperative follow-up was done with clinical examination and determination of CA19-9 and carcinoembryonic antigen (CEA) levels, and ultrasound and computed tomography (CT) scans were performed regularly. Follow-up data were obtained for all patients by establishing contact with them and their treating physicians. Approval was obtained from the ethics committee of Lokman Hekim University on 30/06/2020 with the decision number 2020/056.

\section{RESULTS}

Of 6.114 patients in whom LC was attempted, 5.948 were included in this study. Patients with pathologically proven gallbladder polyps $(n=149)$ and suspicion of malignancy before surgery $(n=17)$ were excluded. The mean age of patients was $49.3 \pm 11.1$ years (range: $18-83$ years);
4.234 of them $(71.2 \%)$ were female. An abnormal gallbladder wall was found intraoperatively in 124 patients $(2.1 \%)$, while in the remaining 5.824 patients $(97.9 \%)$, the morphologic appearance of the gallbladder was normal. Adenocarcinoma was diagnosed histopathologically in 36 cases (25 females, 11 male) out of 5.948 attempted LCs $(0.60 \%)$. The mean age in this group was 64.08 \pm 18.2 years (range: $36-83$ years) and was significantly higher than the mean age in the group of remaining patients $(\mathrm{p}<0.05)$. Demographic features and pathological results are shown in Table 1. All patients with adenocarcinoma presented with symptoms of acute cholecystitis but no jaundice on admission. Conversion to open surgery was required due to a diagnosis of malignancy on frozen section analysis in sixteen of thirty-six patients. They underwent cholecystectomy, excision of the liver bed and lymph node dissection. In the remaining twenty patients, there was no suspicion of malignancy intraoperatively and routine histopathological studies revealed the diagnosis of gallbladder carcinoma. Only LC was performed and no additional surgery was necessitated because of the low stage of the tumors (adenocarcinoma in situ [pTis] and pT1b) in these patients. No retrieval bag was used to extract the gallbladder and there was no port site metastasis in these twenty patients. The histological tumor stages were pTis in seven patient, pT1b in nine patient (Table 1), pT2 in eleven patient and pT3 in nine patients. None of the patients had pT4 disease or evidence of metastasis. The overall survival time ranged from 7 to 42 months (median: 28 months).

\section{DISCUSSION}

Gallbladder cancer is known for its poor prognosis. The highest gallbladder cancer incidence rates have been reported in women from India, Chile and Pakistan (13). The incidence of incidentally diagnosed gallbladder cancer has been reported to vary, up to $2.85 \%$ (11). In recent years, the incidence of incidental diagnosis has increased, probably because of an increase in the number of elective cholecystectomies (14). In the present study, the rate of incidental gallbladder cancer diagnosis was found to be $0.60 \%$. To the best of our knowledge, this is the lowest rate in the published English language literature. The possible cause of this low incidence rate may be diagnoses at advanced stages caused by the avoidance of elective cholecystectomies in our population. Thus, all patients with adenocarcinoma presented with symptoms of acute cholecystitis. Sixteen patients in our series had been diagnosed with gallstone disease before but had rejected elective cholecystectomies. If these patients had not had complaints caused by cholecystitis, they probably would have been diagnosed at an advanced stage. Female gender and advanced age are demographic risk factors for gallbladder carcinoma (15). 
Table 1. Patient characteristics and follow-up

\begin{tabular}{|c|c|c|c|c|c|c|}
\hline $\begin{array}{l}\text { Patient } \\
\text { No. }\end{array}$ & $\begin{array}{c}\text { Age } \\
\text { (years) }\end{array}$ & Sex & Diagnosis & Stage & Operation & Outcome \\
\hline 1 & 72 & $\mathrm{~F}$ & Postoperatively & pT1b & LC (no additional surgery) & No evidence of disease, $6 \mathrm{~m}$ \\
\hline 2 & 70 & $\mathrm{~F}$ & Postoperatively & pTis & LC (no additional surgery) & No evidence of disease, $18 \mathrm{~m}$ \\
\hline 3 & 65 & $\mathrm{M}$ & Postoperatively & pT1b & LC (no additional surgery) & No evidence of disease, $9 \mathrm{~m}$ \\
\hline 4 & 57 & $\mathrm{M}$ & Postoperatively & pTis & LC (no additional surgery) & No evidence of disease, $17 \mathrm{~m}$ \\
\hline 5 & 50 & $\mathrm{M}$ & Postoperatively & pT1b & LC (no additional surgery) & No evidence of disease, $8 \mathrm{~m}$ \\
\hline 6 & 70 & $\mathrm{~F}$ & Postoperatively & pTis & LC (no additional surgery) & No evidence of disease, $11 \mathrm{~m}$ \\
\hline 7 & 57 & $\mathrm{M}$ & Postoperatively & pTis & LC (no additional surgery) & No evidence of disease, $7 \mathrm{~m}$ \\
\hline 8 & 66 & $\mathrm{~F}$ & Postoperatively & pTis & LC (no additional surgery) & No evidence of disease, $16 \mathrm{~m}$ \\
\hline 9 & 52 & $\mathrm{M}$ & Postoperatively & pTis & LC (no additional surgery) & No evidence of disease, $8 \mathrm{~m}$ \\
\hline 10 & 50 & $\mathrm{M}$ & Postoperatively & pT1b & LC (no additional surgery) & No evidence of disease, $14 \mathrm{~m}$ \\
\hline 11 & 61 & $\mathrm{M}$ & Postoperatively & pTis & LC (no additional surgery) & No evidence of disease, $6 \mathrm{~m}$ \\
\hline 12 & 76 & $\mathrm{~F}$ & Postoperatively & pT1b & LC (no additional surgery) & No evidence of disease, $18 \mathrm{~m}$ \\
\hline 13 & 66 & $\mathrm{~F}$ & Postoperatively & pT1b & LC (no additional surgery) & No evidence of disease, $9 \mathrm{~m}$ \\
\hline 14 & 75 & $\mathrm{~F}$ & Postoperatively & pT1b & LC (no additional surgery) & No evidence of disease, $18 \mathrm{~m}$ \\
\hline 15 & 75 & $\mathrm{~F}$ & Postoperatively & pT1b & LC (no additional surgery) & No evidence of disease, $17 \mathrm{~m}$ \\
\hline 16 & 63 & $\mathrm{~F}$ & Postoperatively & pT1b & LC (no additional surgery) & No evidence of disease, $15 \mathrm{~m}$ \\
\hline 17 & 66 & $\mathrm{~F}$ & Intraoperatively & pT3 & $\begin{array}{l}\text { Converted from LC to OC }+ \\
\text { LBx + LND }\end{array}$ & No evidence of disease, $54 \mathrm{~m}$ \\
\hline 18 & 54 & M & Intraoperatively & pT2 & $\begin{array}{l}\text { Converted from LC to OC + } \\
\text { LBx + LND }\end{array}$ & No evidence of disease, $28 \mathrm{~m}$ \\
\hline 19 & 72 & $\mathrm{~F}$ & Intraoperatively & pT3 & $\begin{array}{c}\text { Converted from LC to OC + } \\
\text { LBx + LND }\end{array}$ & No evidence of disease, $32 \mathrm{~m}$ \\
\hline 20 & 73 & $\mathrm{~F}$ & Intraoperatively & pT3 & $\begin{array}{c}\text { Converted from LC to OC + } \\
\text { LBx + LND }\end{array}$ & No evidence of disease, $52 \mathrm{~m}$ \\
\hline 21 & 68 & $\mathrm{~F}$ & Intraoperatively & pT2 & $\begin{array}{c}\text { Converted from LC to OC + } \\
\text { LBx + LND }\end{array}$ & No evidence of disease, $25 \mathrm{~m}$ \\
\hline 22 & 49 & M & Intraoperatively & pT3 & $\begin{array}{l}\text { Converted from LC to OC + } \\
\text { LBx + LND }\end{array}$ & No evidence of disease, $34 \mathrm{~m}$ \\
\hline 23 & 72 & $\mathrm{~F}$ & Intraoperatively & pT3 & $\begin{array}{l}\text { Converted from LC to OC }+ \\
\text { LBx + LND }\end{array}$ & No evidence of disease, $54 \mathrm{~m}$ \\
\hline 24 & 61 & $\mathrm{~F}$ & Intraoperatively & pT2 & $\begin{array}{c}\text { Converted from LC to OC + } \\
\text { LBx + LND }\end{array}$ & No evidence of disease, $22 \mathrm{~m}$ \\
\hline 25 & 58 & M & Intraoperatively & pT3 & $\begin{array}{l}\text { Converted from LC to } \mathrm{OC}+ \\
\mathrm{LBx}+\mathrm{LND}\end{array}$ & No evidence of disease, $42 \mathrm{~m}$ \\
\hline 26 & 53 & M & Intraoperatively & pT3 & $\begin{array}{c}\text { Converted from LC to OC }+ \\
\text { LBx }+ \text { LND }\end{array}$ & No evidence of disease, $52 \mathrm{~m}$ \\
\hline 27 & 69 & $\mathrm{~F}$ & Intraoperatively & pT2 & $\begin{array}{l}\text { Converted from LC to OC }+ \\
\text { LBx + LND }\end{array}$ & No evidence of disease, $32 \mathrm{~m}$ \\
\hline 28 & 66 & $\mathrm{~F}$ & Intraoperatively & pT3 & $\begin{array}{c}\text { Converted from LC to OC + } \\
\text { LBx }+ \text { LND }\end{array}$ & No evidence of disease, $44 \mathrm{~m}$ \\
\hline 29 & 36 & $\mathrm{~F}$ & Intraoperatively & pT3 & $\begin{array}{c}\text { Converted from LC to OC + } \\
\text { LBx + LND }\end{array}$ & No evidence of disease, $52 \mathrm{~m}$ \\
\hline 30 & 76 & $\mathrm{~F}$ & Intraoperatively & pT2 & $\begin{array}{l}\text { Converted from LC to OC + } \\
\text { LBx + LND }\end{array}$ & No evidence of disease, $32 \mathrm{~m}$ \\
\hline 31 & 78 & $\mathrm{~F}$ & Intraoperatively & pT2 & $\begin{array}{c}\text { Converted from LC to OC + } \\
\text { LBx + LND }\end{array}$ & No evidence of disease, $57 \mathrm{~m}$ \\
\hline 32 & 80 & $\mathrm{~F}$ & Intraoperatively & pT2 & $\begin{array}{c}\text { Converted from LC to OC + } \\
\text { LBx + LND }\end{array}$ & No evidence of disease, $52 \mathrm{~m}$ \\
\hline 33 & 81 & $\mathrm{~F}$ & Intraoperatively & pT2 & $\begin{array}{c}\text { Converted from LC to } \mathrm{OC}+ \\
\text { LBx + LND }\end{array}$ & No evidence of disease, $33 \mathrm{~m}$ \\
\hline 34 & 85 & $\mathrm{~F}$ & Intraoperatively & PT2 & $\begin{array}{l}\text { Converted from LC to OC }+ \\
\text { LBx + LND }\end{array}$ & No evidence of disease, $26 \mathrm{~m}$ \\
\hline 35 & 85 & $\mathrm{~F}$ & Intraoperatively & pT2 & $\begin{array}{c}\text { Converted from LC to OC + } \\
\text { LBx + LND }\end{array}$ & No evidence of disease, $22 \mathrm{~m}$ \\
\hline 36 & & $\mathrm{~F}$ & Intraoperatively & pT2 & $\begin{array}{c}\text { Converted from LC to OC }+ \\
\text { LBx + LND }\end{array}$ & No evidence of disease, $18 \mathrm{~m}$ \\
\hline
\end{tabular}


In the present study, the male to female ratio was found to be 1:2 in patients with incidentally diagnosed gallbladder cancer, and the mean age of this group was significantly higher than the mean age of the remaining patients. The median survival for the incidentally-found group has been reported to range from 8.1 to 68 months (Table 2) (3-10).

Table 2. Patient and pathological characteristics of incidental gallbladder cancer series

\begin{tabular}{lcccccccc}
\hline Author & Year & $\mathbf{N}$ & $\begin{array}{c}\text { Cancer } \\
(\boldsymbol{\%})\end{array}$ & $\begin{array}{c}\text { Female } \\
\text { /Male } \\
\text { ratio }\end{array}$ & $\begin{array}{c}\text { Mean } \\
\text { age }\end{array}$ & $\begin{array}{c}\text { pTis, } \\
\text { pT1 pT2, }\end{array}$ & $\begin{array}{c}\text { pT3, } \\
\text { pT4 }\end{array}$ & $\begin{array}{c}\text { Median } \\
\text { survival } \\
\text { (months) }\end{array}$ \\
\hline Sarli et al. (3) & 2000 & 2300 & $9(0.39)$ & $6 / 3$ & 62.3 & 4 & 5 & $\mathbf{1 2}$ \\
\hline Antonakis et al. (4) & 2003 & 5539 & $11(0.2)$ & $8 / 3$ & 57 & 0 & 11 & 8.1 \\
\hline Yamamoto et al. (5) & 2005 & 1663 & $9(0.54)$ & $4 / 5$ & 73 & 4 & 5 & 19 \\
\hline Shimizu et al. (6) & 2006 & 1195 & $10(0.84)$ & $7 / 3$ & 61.4 & 4 & 6 & 62.5 \\
\hline Kwon et al. (7) & 2008 & 1793 & $38(2.12)$ & $21 / 17$ & 66 & 20 & 18 & 68 \\
\hline Tantia et al. (8) & 2009 & 3205 & $19(0.59)$ & $14 / 5$ & 56 & 16 & 3 & 18.4 \\
\hline Choi et al. (9) & 2009 & 3145 & $33(1.05)$ & $24 / 9$ & 63 & 12 & 21 & 46.3 \\
\hline Zhang et al. (10) & 2009 & 10466 & $20(0.19)$ & $16 / 4$ & 65.7 & 8 & 12 & 43 \\
\hline
\end{tabular}

In the present study, the median survival time was 28 months, which compares favorably with previously reported survival times in the literature. The therapeutic approach for gallbladder cancer was applied according to the stage of the tumors. In the present study, five patient with a pTis and six patient with a pT1b underwent simple cholecystectomies without any additional surgery. There was no suspicion of malignancy intraoperatively, and routine histopathological studies revealed the diagnosis of gallbladder carcinoma in these patients. When we examined the treatment of early stage tumors in the literature, cholecystectomy alone was a sufficient therapy for T1a tumors $(7,16,17)$, but the possible necessity of further surgery for $\mathrm{T} 1 \mathrm{~b}$ tumors is under debate $(7,16,18-23)$. Some authors have recommended simple cholecystectomy for $\mathrm{T} 1 \mathrm{~b}$ tumors $(7,16,19,21)$, while others have recommended additional surgery including liver bed resection and lymph node dissection $(20,22,23)$. Liver resection and regional lymphatic dissection should be performed for $\mathrm{T} 2$ tumors because nodal metastasis has been reported in up to $50 \%$ of cases (16).
Furthermore, T3 tumors have also been treated in the same way as T2 tumors, but the long-term survival rate for patients with $\mathrm{T} 3$ tumors has been approximately 5\% (22). We performed excision of the liver bed and lymph node dissection in addition to a cholecystectomy in five patient with $\mathrm{T} 2$ tumors and eleven patients with $\mathrm{T} 3$ tumors.

\section{CONCLUSION}

The incidence of incidental gallbladder cancer has been reported to vary, up to $2.85 \%$. In this single-center study, the rate of incidental gallbladder cancer was found to be $0.60 \%$. Female gender and advanced age are demographic risk factors for gallbladder carcinoma. Although gallbladder cancer runs a short course with a poor prognosis, incidentally diagnosed tumors are often found in early stages and have a better prognosis.

\section{ACKNOWLEDGEMENTS}

The authors wish to extend a sincere thank you for assistance in completing this project to the staff of the Pathology Department at Ankara Numune Research and Education Hospital. The authors did not receive any funding for this Project.

\section{REFERENCES}

1. Jemal A, Siegel R, Ward E, Murray T, Xu J, Smigal J, et al. Cancer statistics, 2006. CA Cancer J Clin. 2006; 56: 106-30.

2. Frauenshuh D, Greim R, Kraas E. How to proceed in patients with carcinoma detected after laparoscopic cholecystectomy. Langenbecks Arch Surg. 2000; 385: 495-500.

3. Sarli L, Contini S, Sansebastiano G, Gobbi S, Costi R, Roncoroni L. Does laparoscopic cholecystectomy worsen the prognosis of unsuspected gallbladder cancer?. Arch Surg 2000; 135: 1340-4.

4. Antonakis P, Alexakis N, Mylonaki D, Leandros E, Konsyadoulakis M, Zografos G, et al. Incidental finding of gallbladder carcinoma detected during or after laparoscopic cholecystectomy. Eur J Surg Oncol. 2003; 29: 358-60.

5. Yamamoto H, Hayakawa N, Kitagawa Y, Katohno Y, Sasaya T, Takara D, et al. Unsuspected gallbladder carcinoma after laparoscopic cholecystectomy. J Hepatobiliary Pancreat Surg. 2005; 12: 391-8.

6. Shimizu T, Arima Y, Yokomuro S, Yoshida H, Mamada Y, Nomura T,et al. Incidental gallbladder cancer diagnosed during and after laparoscopic cholecystectomy. J Nippon Med Sch. 2006; 73: 136-40.

7. Kwon AH, Imamura A, Kitade H, Kamiyama Y. Unsuspected gallbladder cancer diagnosed during or after laparoscopic cholecystectomy. J Surg Oncol. 2008; 97: 241-5.

8. Tantia O, Jain M, Khanna S, Sen B. Incidental carcinoma gall bladder during laparoscopic cholecystectomy for symptomatic gall stone disease. Surg Endosc. 2009; 23: 2041-6. 
9. Choi SB, Han HJ, Kim CY, Kim WB, Song T, Suh SO, et al. Incidental gallbladder cancer diagnosed following laparoscopic cholecystectomy. World J Surg. 2009; 33: 2657-63.

10. Zhang WJ, Xu GF, Zou XP, Wang WB, Yu JC, Wu GZ, et al. Incidental gallbladder carcinoma diagnosed during or after laparoscopic cholecystectomy. World J Surg. 2009; 33: 2651-6.

11. Mori T, Souda S, Hashimoto J, Yoshikawa Y, Ohshima M, et al. Unsuspected gallbladder cancer diagnosed by laparoscopic cholecystectomy: a clinicopathological study. Surg Today. 1997; 27: 710-3.

12. AJCC cancer staging manual. In: Edge S, Byrd DR, Compton CC, Fritz AG, Greene F, Trotti A,et al., editors. 7th ed. New York (USA): Springer, 2010; 347-77.

13. Goldin R, Roa J. Gallbladder cancer: a morphological and molecular update. Histology. 2009; 58: 218-29.

14. Steinert R, Nestler G, Sagynaliev E, Müller J, Lippert H, Reymond MA, et al. Laparoscopic cholecystectomy and gallbladder cancer. J Surg Oncol. 2006; 93: 682-9.

15. Furlan A, Ferris JV, Hosseinzadeh K, Borhani AA. Gallbladder carcinoma update: multimodality imaging evaluation, staging, and treatment options. AJR Am J Roentgenol. 2008; 191: 1440-7.

16. Yamaguchi K, Chijiiwa K, Saiki S, Nishihara K, Takashima M, Kawakami K, et al. Retrospective analysis of 70 operations for gallbladder carcinoma. Br J Surg. 1997; 84: 200-4.

17. Yildirim E, Celen O, Gulben K, Berberoglu U. The surgical management of incidental gallbladder carcinoma. Eur J Surg Oncol. 2005; 31: 45-52.

18. You DD, Lee HG, Paik KY, Heo JS, Choi SH, Choi DW, et al. What is an adequate extent of resection for T1 gallbladder cancers? Ann Surg. 2008; 247: 835-8.

19. Wakai T, Shirai Y, Yokoyama N, Nagakura S, Watanabe H, Hatakeyama K, et al. Early gallbladder carcinoma does not warrant radical resection. Br J Surg. 2001; 88: 675-8.

20. Principe A, Del Gaudio M, Ercolani G, Golfieri R, Cucchetti A, Pinna AD, et al. Radical surgery for gallbladder carcinoma: possibilities of survival. Hepatogastroenterology. 2006; 53: 660.

21. Puhalla H, Wild T, Bareck E, Pokorny H, Ploner M, Soliman T, et al. Long-term follow-up of surgically treated gallbladder cancer patients. Eur J Surg Oncol. 2002; 28: 857-63.

22. Cubertafond P, Gainant A, Cucchiaro G. Surgical treatment of 724 carcinomas of the gallbladder. Results of the French surgical association survey. Ann Surg. 1994; 219: 275-80.

23. Varshney S, Buttirini G, Gupta R. Incidental carcinoma of the gallbladder. Eur J Surg. Oncol 2002; $28: 4$ 10. 